\title{
In the Hammock of Memory
}

\section{Ernest Ilisca*}

Université Paris-Sorbonne | Paris, França

ernest.ilisca@gmail.com

\section{After-War}

Remembrances are sensorial, they hang corporal feelings on static pictures. Memory keeps them enshrined in the middle of a story. My first recollections date from 1947. I was 3 years old and left Paris with my dear mother, Rosa, to meet my family and my dear cousin Moshe.

In route to Bucharest. The journey lasted 3 days and 3 nights! By Train! A procession of carriages passing through the mosaic of post-war Europe, after the disaster ! Rosa had hanged a hammock on the ceiling of the wagon, placed me in the hollow of its net, swinging in with the rhythmic motion of the train, that jerky rolling of accelerations and sudden braking's. I still feel that swing inside of me, and when I remember it, I am filled with a delightful warmth. As if by miracle, at that very moment, a train whistle rips the night to pieces, a new joy brings me back to that journey of my childhood, and I feel again the unlikelihood of my existence.

Strangely enough, my first remembrance brings to mind Rosa's hands peeling a hard-boiled egg. Seen from above, from the height of the hammock, that plunging picture follows the motion of Rosa's fingers, the landscape being projected on the window screen and flowing backwards. That image, engraved in my memory, announced that mother would catch me and slide me down in her arms, for dinner. That blur of happiness came to an end at Bucharest terminal, and my second remembrance is frightening. Once off the train, a fresh breeze engulfed me in the middle of the welcoming and enthusiastic family, but my attention was fixed upon the Rumanian station guard, more particularly on his cap. That image became a horrific symbol, that of a frightening authority.

\section{Twists and Turns}

32 years later in 1979, I embarked on a new journey through Germany and Poland to reach Vienna. Rosa had lived there, and studied in German from 1927 to 1929.

Like in 1947, and like all communist countries, Poland was grey and gloomy. Like in 1947, the train whistle was tearing the night and the fog to pieces. Time turned backwards, took me back to the past. The smell of coal, and its smoke were wrapping

\footnotetext{
* Professor Emérito do Laboratoire Matériaux et Phénomènes Quantiques, na Universidade de Paris-Sorbonne.
} 


\section{Arquivo Maaravi}

Revista Digital de Estudos Judaicos da UFMG ISSN: 1982-3053

up a nightmare. In that enveloping smoke, I clearly recognized carriages of Jews, locked in cattle wagons, crossing through the anti-Semitic Poland. In Poznan, I got on a night train to Vienna, I climbed on a top bunk, hoping to escape from the sadness of the ugly world. Lying down, flat on my stomach, my nose in front of the window, swinging with the vibrating suspension, I followed the slow sinking of the declining orange behind the curtain of polar trees and aspens. As in my earlier trip, the mist was emerging from the fields, erasing the meadows, the farms and their peasants. Slowly my memories appeared, emerging from the mist; I felt again the swinging of the hammock numbing my legs, I saw again the white smoke covering the night, the dull plains running by, and as all remembrances were fading, the last orange glimpses slowly slipped me into a quiet dream...

Suddenly, a strident noise rattled! I awoke abruptly... The brakes were grinding, a few shakings followed and the train stopped! Was I still dreaming? No! The reality was tougher! Loud shouts became nearer, a cap appeared and under it, a face was shouting: Passport! Visa! I stared at the cap fixedly, unable to comprehend. But the commotion was in full swing... The cap had found my suitcase, snatched it, passed-it on to another cap, who threw it on the platform...! Again, loud cries everywhere! Quickly, I grabbed my clothes, jumped out of my bunk, ran through the corridor while pulling on my shirt and jumped out on the platform. Another cap whistled, and the wagon procession disappeared. Left alone in the dark? Not exactly! Slowly getting accustomed to the starlight, adjusting my trousers, I became aware of 3 joyful figures, enjoying a bottle of Vodka on a bench. They invited me to share it with them! I don't speak the Polish language, but I realized that I was at the Czechoslovakian border without a Visa, drinking Vodka in the middle of nowhere, since I had ignored the necessity of a Visa to cross the country by night train! Loneliness in a lonely spot under a starlit sky! That unusual and strange companionship evoked the dizzily feeling that time was again running backwards!

I had to return to Warsaw. Lying again in a night train, on a top bunk, sleepy... I was vaguely listening to the continuous chitchat of a Polish aristocrat mother talking incessantly about her exiled daughter; all alone in Vienna... her poor little lonely daughter... All around, the grey factories were still flying backwards, always surrounded by that vaporous and smoky fog. Warsaw came to me yawning, on such an improbable milky day. Free from the caps, I was strolling about, alone with my suitcase in the silent and deserted streets. No cars, no human beings, nobody!

No sound ... except for the sliding friction of my rolling suitcase!

Suddenly! At the far end of the street, a black cloud appeared, growing and approaching, a murmuring deep sound invaded the space around. From the end of the street, emerged placards, flags and crosses. I understood that I had arrived in Warsaw at the very moment when Karol Wojtyla, the new Polish Pope John-Paul the second was visiting his native country for the first time, continuously chanting: 


\section{Arquivo Maaravi}

“Don't lose your spiritual freedom!”... “Don't lose your spiritual freedom!”... A million of Polish people were approaching! And the crowd devoured me! I had no choice other than crossing that multitude of inflamed faces staring at the sky and singing canticles.

Fortunately, one hour later, that crowd rejected me like one spits out a cherry pit! I walked on further, all the way to the airport, got on a plane... and landed that very same evening in Vienna. A new music was flying everywhere: the German language.

\section{In the Family Nest}

32 years earlier, in 1947, I had arrived in Bucharest. The sound of German was all over around. At that time Moshe was called Marcel. I remember a staircase. That third memory bathes the steps, where Marcel and I were playing with a young handicapped girl, called Erika. We were playing and talking in German. Today, I cannot understand from where those words had come from. Above, in the large Rumanian apartment, the women: sisters, and mother, are talking joyfully. Men are mostly elsewhere, Uncle Eliezer at work, Uncle Harry in a soviet labor camp, Grand Father Jacob is muttering, he mutters rhythmically in a corner! Only the benevolent Uncle Bubi smiles ironically at the ladies. The women: Melanie, Sabina, Rosa and Charlotte chatter loudly and laugh happily.

I'm running all over the place, and after a while finds refuge on my mother's knees, listening attentively to that fascinating discussion among the sisters, in hochdeutsch, ${ }^{1}$ they say. Marcel sits in the middle, enthroned on a glowing tricycle. I'm red with envy. He refuses firmly to lend it to me and even, forbids me to touch it! But a few days later, finally he accepts! Probably, Sabina had forced him? I jumped quickly on the tricycle, before he could change his mind! My fourth remembrance stares at me, cycling down the long corridor, when suddenly, I stop in astonishment! Uncle Bubi is shaving, in the bathroom... in front of the mirror. The door is open... I stare at him; his face is covered by a white, thick and creamy foam. Bubi holds in his right hand a sharp and shining razor! He turns around, smiles at me, raises his razor high and says: "What do you need a pipi for? What's that gadget for? It's of no use! Can I cut it off?" Stupefied, horrified, I abandon the gleaming tricycle and run away shouting: “Mutter! Mutter!"... “Maman".

\section{Postscript}

Esta crônica é uma versão de um conto que dediquei a minha família materna durante uma recente comemoração em Cesareia, em 2019. Esse encontro juntou os quatro ramos vindos de meus avós maternos que chegaram na Bucovina em Czernowitz, no início do século 20. Esses avós e os seus quatro filhos tiveram uma

\footnotetext{
${ }^{1}$ Hochdeutsch é uma variante oficial do alemão, utilizada nas escolas, empresas, na mídia e entre falantes de diferentes dialetos do alemão.
} 
vida burguesa e cultural nesta cidade tolerante que atraiu uma grande população judia. Toda a família falava alemão, um hochdeutsch, apreciado no império austrohúngaro. Minha mãe estudou em Viena e emigrou depois para a França, no início dos anos 1930. Durante a Segunda Guerra Mundial, meus pais sobreviveram, escondidos num pequeno vilarejo francês, onde nasci. Uma parte da família que ficou na Romênia foi morta pelos nazistas e a outra parte se escondeu num porão em de Bucareste. Depois da guerra, alguns emigraram para Israel e outros para a França. Este relato conta, principalmente, uma viagem que fiz com minha mãe em 1947, depois da guerra, com a idade de 3 anos, para Bucareste para encontrar a família sobrevivente. Inseri também, neste relato, a rememoração de uma outra viagem que aparecia como um eco da primeira. Em 1979, percorri um caminho através da Europa Central para chegar em Viena, onde minha mãe viveu nos anos 1920. Este conto tenta reunir essas três viagens (1947, 1979 e 2019) e dar a elas uma forma poética apropriada para conservar um rastro de uma errância judaica na rede da memória. Os fatos relatados são reais, mas a escrita foi inspirada por duas autobiografias: The Story of a Life, de Aharon Appelfeld, e Fala, memoria: uma autobiografia revisitada, de Vladimir Nabokov.

Recebido em: 03/03/2020.

Aprovado em: 13/03/2020. 